\title{
Revisiting Norbert Elias's Sociology of Community: Learning from the Leicester Restudies
}

Abstract: Since 2001 we have been engaged in a restudy of three linked Leicester projects The Employment of Married Women in a Leicester Factory (1959-1962), The Adjustment of Young Workers to Work Situations and Adult Roles (1962-1964) and The Established and the Outsiders (1965). The three projects contain a number of striking overlaps, not least Elias's formulation of communities as figurations through which communal behavioural standards are established, learned and maintained. Whether in the different Zones of Winston Parva, or in the large hosiery factories of Leicester, people learned the selfcontrol of drives and affects 'according to the pattern and extent of socially given drive and affect regulation' of that time and that community. In this paper we outline the background to the three restudies and link them to Elias's work on community and the broader canon of community studies. We then consider methodological lessons learnt from our restudies - in particular, the practical process of restudies, the definitional problems of what constitutes a restudy, and the value of visual images and walking the field. We conclude by reflecting upon the analytical promise of community restudies

Keywords: Norbert Elias; Leicester Restudies; Young Workers; Gender and Work; Community Restudies. 


\section{Introduction}

The concept of community has been central to many key works in the sociological literature of the last sixty or more years (see Frankenberg 1957 and 1966; Stacey 1960; Willmott and Young 1960; Rosser and Harris 1965; Pahl 1984; Crow 2002). Its centrality often turns upon the fact that 'community' can be an all encompassing concept covering many aspects of social life within particular settings, places or times. It can also encapsulate a diverse range of other concepts including housing, locality, urbanisation, citizenship, family, work, employment, relationships and so forth. Community can be operationalized as a cross-sectional snapshot, recording and reflecting upon communities as they are now, or it can be viewed more longitudinally with communities being considered as a social phenomenon emerging and changing over time. As such, Elias's (1974: ix) assertion that 'the figurations of people which are investigated today under the name 'community' vary a great deal' still holds true for contemporary studies of community. This complex and multifaceted nature of research on community has been an emerging concern in our own series of restudies over the last ten years.

Since 2001 we have been engaged in a restudy of three interlinked research projects undertaken originally by former colleagues in the Leicester sociology department of the 1950s and 1960s - The Employment of Married Women in a Leicester Factory (1958 - 1961), Adjustment of Young Workers to Work Situations and Adult Roles (1962-1965), and The Established and The Outsiders (1958-1965). These restudies are at various stages of completion and despite their differing origins (two are large scale, publicly funded, empirical studies, the other a reworking of an MA thesis), there are a number of striking overlaps, not least being undergirded to various degrees by Elias's formulation of communities as figurations through which communal behavioural standards are 
established, learned and maintained. Elias's approach to community builds directly on the central thesis he outlined in The Civilising Process (2000). As Mennell elaborates, Elias considers two levels of civilising process, the individual level where individuals learns the adult standards of behaviour and feelings of their society and, second the social relational level or how these behavioural standards have emerged and changed through long term processes over generations and time (Mennell 1990: 207; see also Author B and Author A 2006). Elias conceptualised this as the interrelationship between sociogenesis (the processes of development and transformation in social relations) and psychogenesis (the processes of development and transformation in the psychology, personality or habitus that accompany such social changes) (Van Krieken 1998). The notion of community is used by Elias to exemplify this and his adoption of Homines aperti (see below) 'as a guiding image of humans and the societies they form: of open, pluralities of bonded and interdependent individuals' (Author B and Hughes 2011: 681). Communities are central to these long-term social processes, pointing to the interdependencies that bind people to each other (Elias 1974; xviii), and are a relational, or more precisely figurational, nexus through which behavioural standards emerge, are transformed and are learnt. In the context of the restudies outlined below, and whether it is in the different Zones of Winston Parva, or in the large hosiery factories of Leicester, people learned the selfcontrol of drives and affects 'according to the pattern and extent of socially given drive and affect regulation' of that time and that community (Elias 1980: 202). At the time of these studies between the late 1950s and mid 1960s, the adjustment to adulthood centres on leaving school and entering paid employment and it is through working that adult behavioural standards are learnt (see Author B). Yet over the course of the last forty years the communities we have been studying have been witness to a massive transformation in how you people make the transition to work, the roles of women in work, and a massive decline in the traditional industries once so dominant in this locality. 
The move away from the fixed, linear education to work trajectories of the 1960's, the increased transitions into precarious employment, underemployment or mass unemployment have all meant the processes through which young people acquire the behavioural standards of adulthood have become less certain and more complex. As other authors have reflected, this, along with the accompanying de-industrialisation of these communities, may represent something of a 'decivilizing process' (see, for example, Mennell, 1990; Van Krieken 1999 and 2011; De Swann 2003) and a breakdown in the stability and consistency of on-going social relations' (Van Krieken 1999: 297)

Through our restudies we have data from two points in time, within the same community settings, that afford us unique insight into the change and transformation experienced in, and by, these communities as well as, what Laub and Sampson (2003: 302) refer to as examining the 'within-individual variability over nearly the entire life course', (see Author B and Author A; Author B and Author A; Author A and Author B). Of central concern to this paper, through our reworking of these three projects, we have generated particular insight into the practicalities, methodological problems and empirical and theoretical promise that community restudies can offer contemporary social science. As such this paper has three broad main aims. First, we offer a brief introduction to each of the three restudies before linking them to Elias's sociology of community. It is not our intention here to offer a full exposition of Elias' theoretical model of community but more to establish the basis of the three Leicester projects in the community studies canon. Second, we outline the main lessons we have learned from our experiences of undertaking restudies including the practical process of restudies, the definitional problems surrounding the concept of restudies and the role of archival research. We also draw upon our use of visual methods as an important methodological tool in our approach to restudies. We explore the use of photo-elicitation, photo-documentation and 
the value of 'walking the field' as a starting point for understanding more about the studies we are revisiting. Finally, we conclude by returning to Elias's work on community and reflecting on the promise that community restudies offers in relation to what Elias (1987) termed the retreat of sociologists into the present.

\section{The Leicester Studies: Gender, Youth, Work and Community in Leicester}

The Employment of Married Women in a Leicester Hosiery Factory (1959 - 1962)

In 1959 the Department of Sociology at the University of Leicester was awarded a total grant of $£ 2,025$ by the Department for Scientific and Industrial Research (DSIR) Human Science Committee to undertake research into the employment of married women in a Leicester hosiery factory 'having regard to the problems posed both for industrial management and family life' (Neustadt and Brown 1959: 1). The location for the research was the N. Corah (St. Margaret) Ltd. - the largest single hosiery factory in Leicester, employing some three and a half thousand women in the late 1950s. The research team from Leicester were Ilya Neustadt as project director, and Richard Brown as Senior Research Officer, and from the London School of Economics, Professor Richard Titmuss as co-investigator and Miss J. T. Henderson as a part-time research assistant who undertook the interviews in the field. The London School of Economics connection was vital as the Leicester married women project was a replication of a project led by Pearl Jephcott, overseen by Titmuss, on women workers at the Peak Frean biscuit factory in Bermondsey - published later as the seminal Married Women Working (1962). It was through the support of Titmuss and Seear that Leicester received the funding from DISR for the study (Titmuss 1958: DSIR 1958), with Titmuss arguing that the study of women working for Corah in Leicester would offer useful comparative data to the Bermondsey study and establish Leicester as a centre for high quality, empirically informed, sociological research (Titmuss 1958: 1). 
Using a combination of interviews with around ten per cent of the women working at the Corah factory, observations, case studies and a detailed analysis of Corah factory records, the aims of the research were to explore: i) the extent and nature of absenteeism and labour turnover and stability; variations in earnings and outputs between different categories of employees; ii) the characteristics of family and household organisation of women who go out to work; relationship of these to employment in the factory; attitudes to work, including attitudes to supervision; iii) compare a small number of households where the wife goes our to work with a similar number of households where the wife stays at home; iv) the problems for managers and supervisors which arise from the employment of large numbers of married women; and finally iv) the context both of the general local situation with regard to the employment of married women, and of the result of other empirical studies in this field.

From the archival material it is clear that during 1959 a considerable amount of the fieldwork was completed. For example Neustadt (1959) reports that five hundred questionnaires had been completed by women working in selected departments at the Corah factory, pilot interviews had been completed and the interview sample identified, preliminary and formal interviews had been held with management and supervisory staff and analysis of company records relating to absenteeism and turnover was ongoing. In 1959 Neustadt applied, again with the support of Titmuss, to extend the grant until April 1962 and requested a further $f, 3,961$ to fund the analysis of the data collected to date, provide support for further observations and intensive interviews and to undertake intensive studies of family and household organisation. Brown et al (1964: 26) report that a further forty interviews were undertaken with supervisors about their attitudes to and experiences of the employment of married women. However, despite the extension to 
the project funding, and the considerable time spent collecting data in the field, the Brown et al (1964) paper was the only tangible outcome from this project, with the remainder of the research being 'lost' within this history of sociology at Leicester.

Adjustment of Young Workers to Work Situations and Adult Roles (1962-1965)

Towards the end of 1961, and shortly before the funding ended for the Married Women Project, Elias and Neustadt, along with others in the Leicester sociology department applied again to the DSIR for funding for a second project the Adjustment of Young Workers to Work Situations and Adult Roles. DSIR funding provided an initial grant of $£ 15,000$ for this research to be carried out between 1963 and 1965 to allow the team to explore the problems young people encounter during their adjustment to their work situations and their entry into adult worlds. For Elias, the transition from school to work constituted a 'shock' experience and he argued that young people would experience real difficulties in adjusting to their new role as adults and workers. Unlike the other school to work projects of the time (see, for example, Carter 1962), Elias argued strongly that he wanted the Young Worker Project, as it became known, to move away from the essentially 'adult centred' research of others to focus on the problems '... which confront, and which are experienced by the young generation itself (Elias 1962: 1).

Fieldwork began in 1962, comprising an interview-based survey exploring every aspects of the transitional experience for nearly 900 young adults in Leicester. The survey instrument covered all aspects of the young people's lives including home, work, family, leisure, and it incorporated an employment event history diary. The sample was drawn from young adults from the Youth Employment Office index of all Leicester school leavers from the summer and Christmas of 1960 and the summer and Christmas of 1962. By 1964882 interviews in addition to a pilot survey of 28 interviews had been 
completed. Yet despite the completion of the fieldwork the high aspirations for the Young Worker Project were never to be realised. In the October of 1962, Elias was appointed to a Chair in Sociology at the University of Ghana and, although Elias attempted to direct the project remotely, it became characterised by acrimony, distrust and lack of direction (see Author B and Author A). In 1964, the research team resigned from the project and other members of staff from the Leicester sociology department distanced themselves from the research. As with the Married Women Project that preceded it, very little was to materialise form this research and, with the exceptions of Kiel et al. (1963), Ashton $(1973,1974)$ and Ashton and Field (1976), the bulk of the data remained unanalysed for over 40 years and were simply left in an attic storeroom.

The Established and The Outsiders (1958-1965)

Published in 1965, and based upon data from the 1950s and early 1960s, The Established and The Outsiders is the only one of the original Leicester studies, in our trilogy of restudies, which was ever published. Based on a MA thesis originally written by John Scotson, and supervised by Elias, the book is an examination of a 'figuration' formed by two working class groups in 'Winston Parva' - the pseudonym for a suburb of the city of Leicester in the English Midlands (Author B, Author A and Hughes, J 2011). Winston Parva is separated physically to the north and the east from other communities by railway lines. It is a 'small community with a relatively old settlement [Zone 1] at its core and two more recent settlements [Zones $2 \& 3$ ] which have formed around it' (Elias and Scotson 1965: ix).

The study began when the original researchers' attention was drawn to the consistently higher delinquency rates in one of the newer settlements (Zone 3 or 'The Estate') of 
Winston Parva. However, their interests quickly moved away from delinquency per se to the 'differences in the character of the neighbourhoods and to their relationship with each other' (Elias and Scotson 1965: ix). Through observations of, and interviews with, local residents, Elias and Scotson discovered that one of the working class groups was clearly dominant (the 'established' in Zone 2 or 'The Village'), and the other group was clearly subordinate (the 'outsiders' in Zone 3), despite being identical 'in terms of the conventional indices of social stratification such as wealth, income, occupations, education, status/prestige' (Author B, Author A and Hughes 2011). The superiority of the working class group in Zone 2 was accepted by both groups 'solely with regard to differences between residents in terms of how long they had lived within the neighbourhood and how "established" they were within the community'. For example, the young people in these two working class areas had radically different transitional experiences and experiences of early adult life. As we have seen in Elias's writing for the Adjustment of Young Workers research (see Author B and Author A 2006), the transition from education to work is central to young people learning the self-control of drives and affects 'according to the pattern and extent of socially given drive and affect regulation' (Elias 1980: 202) or learning socially established adult behavioural standards. The more complex a society, the more complex the transition (Author B and Author A 2006). In The Established and The Outsiders, Elias and Scotson argued that young people in The Village grew up within established communal standards that were uniform and were shared by many families. This made it harder for the young people to 'slip up' and The Village was better able to provide the steady adult control of children which facilitated the growth of stable self-controls (Elias and Scotson 1965: 106). Accordingly, these young people made the transition from education to work more easily, encountering fewer problems in becoming adults. 
By contrast, on The Estate, it was left to individual families to provide standards of conduct. But these behavioural standards and customs differed between families and lacked community reinforcement. Elias and Scotson (1965) report that The Estate 'kids' lacked socially stable role models and were not exposed to the same amount of community control to help control socially unacceptable impulses, making it much harder to grow up on the estate. In short, local community membership had a positive impact on the experiences of one group of young people but a negative impact on the experiences of the other.

\section{Communities Intertwined: Themes and Threads in the Leicester Studies}

The three studies, The Employment of Married Women in a Leicester Factory (1958 - 1961), Adjustment of Young Workers to Work Situations and Adult Roles (1962-1965), and The Established and The Outsiders (1958-1965) have a number of key features in common. At the most basic level all three studies were undertaken within the same location and, in some respects had overlapping sample groups and respondents. For example, many of the women who worked for Corah's would have lived in the community covered by the The Established and The Outsiders. The young people from Winston Parva shared many similar characteristics with the young people in the Young Worker project and, finally a number of the young women in the young worker project worked for Corah. Likewise, the focus for three projects was ostensibly on Leicester working class communities at one point in time as all of the fieldwork for the three studies was undertaken between the mid 1950s and mid 1960s. This was a period marked by high levels of employment within Leicester dominated by hosiery, boot and shoe manufacturing and allied engineering industries. This was a period of relative affluence for the city and, as is documented in The Established and The Outsiders, continued to attract workers from elsewhere in the UK and beyond. Yet beyond, these basic similarities, and as we have 
briefly suggested elsewhere (Author A and Author B) whilst these studies are, on the surface, about 'youth', 'married women' or 'the transformation of an old settlement' they are also all variants of a community study (or even three parts of the same study of community). Although Elias's understanding of community is developed in The Established and The Outsiders, it is perhaps most clearly, and succinctly, articulated in his foreword to Bell and Newby's (1974) The Sociology of Community. Here Elias critiques the short term, abstracted and narrowly focused expositions of community, arguing instead that a full understanding of community was possible only via the adoption of processtheories that do not abstract from the long-term diachronic dimension of social change. For Elias, focusing on the polarities emerging from the 'middle range theories' such as traditional versus modern, urban versus rural, agricultural versus industrial does not allow 'for the understanding and explanation of the continuous process, of the development in the course of which one society transformed itself into another...they develop from one stage to another without any absolute break' (Elias 1974:x). In order to adopt this approach, Elias (1974:xvii) posed two questions:

i. What are the specific interdependencies between people who form with each other that kind of figuration which we call community as distinct from those between people forming other types of figurations?

ii. How and why do these characteristic community bonds change when the structure of the wider society changes?

As such, Elias (2001) also allows us to view communities not as 'static' objects but instead as 'processes' highlighting relationships past, present and (possible) future and which refer to changing balances of power and changing interdependencies. Of particular importance here is Elias's critique of the homo clausus or 'closed personality' perspective that has come to dominate sociology and which leads sociologists to continually view the individual as something existing outside of society and society as existing beyond 
individuals (Elias 2000: 472). The central thrust of Elias's work, as we have suggested above, is underpinned not by homo clausus but by homo aperti - a sociological analysis that emphasises the interdependence of people and traces 'changes in personality structure hand in hand with changes in the structure of human relations in societies as parts of an overall process' (Mennell 1992: 193). In Elias's (2001) analysis he argues that 'I' is an outcome of interactions and relationships with others.

\footnotetext{
...there can be no "I" without 'he', 'she', 'we', 'you' or 'they'. It is plainly misleading to use such concepts as 'I" or ego independently of their position with the web of relationships to which the rest of the pronouns refer. Taken together, the personal pronouns are in fact an elementary form of expression of the fact that every person is fundamentally related to other people, and that every human individual is fundamentally a social being. (Elias 2001: 124)
}

In this sense ' $\mathrm{I}$ ' is not a singular but is instead a plurality with ' $\mathrm{I}$ ' and 'we' being inextricably linked (also see Smart 2007). This has clear implications for how we understand the notion of community. Community is not then a collection of individuals but historically and spatially located relationships or figurations that underpin into the group identities and behavioural standards of that point in time. Re-studying community illuminates these changing relationships, interactions, configurations, power balances and webs of relationship.

The three Leicester studies all address these questions in different, but complementary, ways. For example, the Young Worker Project was not only a study of young workers in Leicester, as the study did not simply focus on work and employment in isolation of all the other aspects of the young respondents lives. Instead the young worker project became a multifaceted and complex project covering a range of factors such as: home 
and family, relationships, education and school, work and employment, income and expenditure and leisure time in Leicester (Author B and Author A) that reveals community identity emerging from the configuration or web of relationships to which the young worker belongs. Put simply, the project focused on how the young people became adults via their interactions with the 'community of adults' in the workplace (see Author B). Likewise, The Married Women's Project was not simply a snapshot of the working conditions of married women working full-time in a Leicester hosiery factory, but instead a study which sought to understand the circumstances which had emerged over time that led one community of women workers to work in a particular way. The study is then not about women workers per se but the circumstances and 'traditions' emerging historically that led to the Leicester factories employing much higher numbers of women in full time roles as compared to the Bermondsey study (Titmuss 1958). The community basis for The Established and The Outsiders is more obvious, but again this project overlaps with the other two in that it also tells us much about 'youth' and 'mothers' in this locality as the two other projects. The bases for all of the studies have

echoes of Bell and Newby's (1971: 19) sentiment that community studies must 'examine the interrelationships of social institutions in a locality', which the three Leicester projects clearly do. In this sense, the Leicester studies have more in common with more classic considerations of community (such as Townsend 1957; Frankenberg 1957; Stacey 1960; Willmott and Young 1960; Rosser and Harris 1965; Pahl 1984) given the sheer breadth, depth and range of issues they cover.

\section{Lessons from the Restudies}

As outlined above, we now have considerable practical experience of restudies and the methodological implications of such an approach. This has enabled us to reflect on the lessons we have learnt from our own experience and from the work of others who have 
carried out similar research (Davies and Charles 2002; Laub and Sampson 2003). In the following discussion we illustrate how, in methodological terms, restudies may represent a more challenging and multi-faceted approach to research than may be apparent at first glance. We cover issues around the following areas: data reuse, community restudies, replications, qualitative longitudinal research and visual sociology.

\section{Revisiting Community: The Problem of Methodological Definitions}

One of the lessons we have learnt has been associated with the need for clarity or the desire to be able to classify and define the methodological approach used when carrying out a restudy. A review of the extant literature around this issue reveals that whilst a number of researchers in the social sciences are revisiting data from other, earlier studies, and carrying out restudies, replication and qualitative longitudinal research, there is not always agreement on how to define such research (Author A and Author B, 2010). What is also often lacking in accounts of data reuse is any sense of how the 'revisiting' researchers approached the data itself and carried out the restudy. As Gillies and Edwards (2005:30) suggest, secondary analysis of qualitative datasets is still quite an unusual approach to social science research and, as a consequence, there is a 'shortage of empirical models exploring methods and practices'.

Although there does seem to be some reluctance to reuse qualitative data, perhaps due to the lack of examples of this type of work, sociological interest in the reanalysis of existing qualitative data has increased over the last decade. This interest is based, in part, on the establishment and growth of the ESRC funded Qualidata Archive based at the University of Essex. As we have argued elsewhere, the existence of the data archive provides social scientists with access to a diverse range of existing qualitative datasets including some of the classic sociological studies of the post-war period (Author B and Author A 2009; 
Author A and Author B, 2010). This access, and the burgeoning interest in the possibilities and opportunities offered by such data, has resulted in well-documented debate around the methodological issues raised by qualitative data reuse. Nevertheless, it is also apparent that existing qualitative data sources remain an under-utilised resource, perhaps because, as others have argued, there is a lack of agreement in the social sciences regarding the extent to which qualitative data can be reused by those who were not involved in generating the data in question.

\section{The Importance of Contextual Data}

Much of the debate around the subject of data reuse is, therefore, concerned with the importance of contextual data and the need for the revisiting researchers to have access to background information on the original project alongside the original data (Heaton, 2004; Savage, 2005, 2007; Moore, 2007). In many ways we were extremely fortunate with the Young Worker Project restudy because the wealth of surviving information we were able to access enabled us to reconstruct the 'story' of the project in a way that has not been possible with the other Leicester studies. Not only had the original data been retained largely intact in the form of detailed paper-based transcripts for each individual, we also had access to a wide range of background documentation relating to the project. This was, in part, due to the meticulous personal archive created by Norbert Elias and deposited, after his death, in a library archive in Marbach, Germany. Other individuals, for example, researchers who had worked on the original project, had also retained correspondence and paperwork such as meeting minutes and draft reports and passed these on to us. By collating these various sources of paper-based documentation we were able to construct a comprehensive picture of the life cycle of the original project. Further to this, we were also able to meet and interview members of the original research team who were prepared to reflect on their experience and understanding of how the project 
developed and ultimately failed. Most valuable of all was the data set itself. Each interview schedule included detailed data on individual experiences not only of the transition from school to work but also recognised the interconnectedness of community, education, employment and family life.

Without any doubt the extent of the surviving background material and data relating to the Young Worker Project was exceptional in its coverage. This made it possible to carry out much more than a traditional restudy and goes well beyond the opportunity open to most secondary researchers. For example, first, we were able to begin by carrying out an analysis of the primary data that had not previously been used; in effect a simple data reuse project that has much in common with work done by others primarily using data stored at the UK Data Archive (see Savage, 2005, 2007). Second, like Savage (2005) we were able to carry out an analysis of the interviewer notes collected at the time, giving us a valuable insight into the concerns of the researchers who carried out the fieldwork and to the logistics of the project. The field notes represented an incredibly rich data source but not all archived projects include documentation of this type and there are wide variations between projects in terms of the extent of surviving paperwork. Third, we were able to trace and reinterview a sample of the original respondents, creating a longitudinal dataset from a one-off cross sectional piece of research. Fourth, the original study was, as argued above, a community study and place was an important element of the research design. The majority of the respondents who were successfully traced continued to live in the same locality and, as such, the data we have collected give us a clear sense of changes in community over time.

\section{Ethical Issues}


As alluded to above, the Young Worker Project is unique in that it encompassed so many aspects of secondary data use. In retrospect it is no surprise that when we came to write a methodological account of how the study has been approached we found it almost impossible to classify and define the methodological underpinning for the work. The multi-faceted and multi-layered nature of the data meant that guidelines and protocols for how to treat the data did not always exist and we had to define what we were doing as we progressed (Author A and Author B, 2009, 2010 and Author B and A forthcoming). A good example of this relates to the ethical issues raised by the revisiting of such data. Unusually we did have access to personal profile data of each individual which made him/her identifiable. This information included not only name and date of birth but also details such as school attended, last known address, early employers and so on. Such data would not, of course, usually be available to those making use of archival data yet given that we had these data we made the decision to make use of them in order to trace individuals and construct a longitudinal study from what was, originally, a cross sectional study. We have written at length about the ethical issues raised by this (see Author A and Author B, 2009 and 2010) and how we dealt with these but given the lack of existing research protocol combined with an unparalleled opportunity to create a rich qualitative, longitudinal data set we devised an ethical procedure appropriate to the data. This, we argue, ensured that our approach made the most of the data but importantly ensured that what we did met current ethical guidelines and was validated by the ESRC in our original application for funding. Subsequently we have also discovered the work of Laub and Sampson (2003) who faced a similar dilemma in tracing respondents from an earlier study and followed a similar ethical procedure to our own.

Dealing with 'Missing Data' 
The importance of contextual data to the secondary analyst has been widely debated in the methodological literature. It is argued, for example, that for the secondary analysis of qualitative data to produce meaningful insight then the researchers require access to contextual information around the original project. This is both a laudable aim and a valid concern and we would argue that having access to this wide range of background material enhanced our understanding of the original project immensely. Nevertheless, whilst the aim is commendable, for the majority of researchers it will not be possible to access even scant documentation relating to pre-existing datasets as, so often, it simply no longer exists or has not been archived. A brief look through data available through the UK Data Archive catalogue suggests that datasets vary enormously in terms of the surviving project documentation. Access to contextual data is, then, often extremely limited and the aim of including this in any analysis is a 'utopian vision' rather than a reality for most researchers. Indeed, surely it is preferable for data, where they exist, to be reused rather than ignored simply due to the lack of contextual data available?

We would not argue with the notion that contextual data are valuable and, where they exist can add to our understanding of the evolution of a project. A lack of such data can present the secondary analyst with methodological challenges but, we would argue that as researchers wishing to revisit historical studies we can only work with the documentation available. In many cases and for various reasons, the only available resources may be the published output from the original project. The Winston Parva project is a case in point. This project is the only one of the three Leicester projects which led to the publication of a book yet this study has very little in the way of surviving background information to draw upon. Our approach in this case has, therefore, been somewhat easier to define methodologically as it is essentially a community restudy that does not involve any form of data reuse. Indeed this distinction between restudies and data reuse has been used as 
a way of defining restudies, with Gillies and Edwards (2005:5) suggesting, for example, that restudies 'stop short of re-analysing the original data'. This is a useful distinction to make as it does help to define the differences between a restudy as opposed to, say, qualitative longitudinal research. Yet we would also argue that the reason restudies do not tend to include a data reuse aspect is because it is rare for the original data to survive therefore impossible for researchers to revisit the data.

Restudies of past community studies are not unusual in the social sciences. The Banbury studies (Stacey, 1960 and Stacey et al., 1975) are a good example of this and more recently Davies and Charles's (2002) restudy of Rosser and Harris's (1965) study of Swansea has continued this tradition. There are a number of similarities between the planned Winston Parva restudy and the Swansea restudy. However, unlike Davies and Charles (2002) and unlike the case of the Young Worker Project, we do not have access to the original researchers as both individuals involved (Elias and Scotson) died some time ago. Neither do we have access to any background material relating to the fieldwork of the project apart from brief mentions to the research in letters relating to other matters. Indeed, what we do know is that the published book on the project was based heavily on the MA dissertation written by Scotson, however, the original work no longer exists in either the University of Leicester library where it is catalogued, or the Elias archive where it is also listed. This leaves us, as researchers, with little to go on apart from the published output, in this case a single published volume. Yet the strength of community studies as a basis for carrying out a restudy is that invariably 'place' continues to exist and, as such, the key primary resource remains wholly accessible to researchers.

Alongside the revisiting of place we plan to re-examine the debates relating to young people in the community and to ascertain any continuities or changes in the roles and 
experiences of young people over time. It is not possible for us to trace and reinterview original participants from the 1958 study as we do not have access to any of the information that would make this possible. It is, however, feasible for us to replicate, to a certain extent, the approach of the original study through a contemporary sociological lens.

\section{The V alue of Visual Sociology and Walking the Field}

Our first methodological decision then, was a simple one, to go and 'walk the field' and revisit the location of the original research, taking photographs as documentary evidence of change over time. Both methodological approaches, walking the field and taking photographs, are increasingly recognised as valid visual approaches to sociological research (Pink, 2006; Pink et al., 2010; Rose, 2007). The act of simply 'walking the field' is less well explored than methods relating to visual images but, as Pink et al (2010:5) suggest, 'the question of the relationship between walking, images and the environment is a rich area for analysis and begs further exploration'. The decision to go and visit the locality was a logical first step in our approach.

Whilst background material was lacking, we had access to a number of photographs of the area taken some 40 years ago when Elias revisited the area. The existence of the original photographs guided our original walk of the field as we deliberately set out to locate and re-photograph the sites where the earlier photographs were taken. Walking the field in this way and taking new photographs enabled us to begin to get a visual sense of how community may have changed over time. As Suchar (2004:162) suggests, the use of photographs in documenting the changing urban landscape, 
'reveal social, political, economic and cultural patterns and characteristics that mark changing cities. The patterns thus revealed can be linked to structural realities and macro-processes that help establish a more textured understanding of urban social transformation'.

By combining these photographs with maps of the area we have been able to pinpoint locations, identified as 'zones' in The Established and The Outsiders, and to begin the process of revisiting and 'testing' the arguments put forward in the original study. From this exercise we have begun to identify that areas classified by Scotson and Elias (1965) as particular zones of the community, based on social class distinctions, may not have been as clear-cut as suggested. This is evident from the photographs included here that show Zone 1, identified by Elias and Scotson as a middle-class residential area, but which consisted only of a very small group of 'semi-detached houses with garages' (p.29). The photographs alone would not have revealed this information. It was only by walking and familiarising ourselves with the neighbourhood that we began to realise that the reality of the urban landscape of Winston Parva is not as depicted in the published account. Thus, the experience of walking the field, combined with both access to photographs of the community at the time of the original study and the published work, has enabled us to question the previously accepted version of community based on the Elias and Scotson research.

\section{INSERT FIGURE 1 HERE}

Our starting point for revisiting the Married Women's Survey was also to 'walk the field' and record photographic images relating to the project, much as we did for the Winston Parva project. The urban landscape of the city has changed immeasurably since the time of original study with many factories associated with the traditional industries having 
either been demolished or converted to a different use, often residential. We visited and documented, by taking photographs of now obsolete factories, the deindustrialization of the city landscape. This chimes with the work of Strangleman (2008:1498) who has highlighted the importance of such 'visual representations of deindustrialization, which, while not setting out to, represent labour by capturing the remains of the physical infrastructure tell us something about work practice'.

The building which housed the Corah factory still exists today and parts of the building are being used by small companies who rent work units in the space. From a site visit it is possible to see the size of the site and to begin to understand the earlier scale of operations at this factory. It was only by walking the field that as researchers we gained an insight into the sheer size and complexity of the Corah Works and began to understand more about the way that work was organised at the factory (see Figure 2). Reinterviews with past employees have not yet commenced but we plan to use our photographs of the defunct factory site as a means of facilitating interviews and 'unlocking memories untapped for decades, helping to explain the 'why' and the 'how' of work as well as the meaning' (Strangleman, 2008: 1500).

As an important local employer much has been written about Corah's, including a history of the organization, so it proved straightforward to gain an insight into the profile of the employer. We also have first hand accounts of working lives at Corah's from the Young Worker reinterviews.

\section{INSERT FIGURE 2 HERE}

The Corah plant, like the vast majority of Leicester's traditional factories producing textiles, closed down fully in the 1990s. The loss of these traditional industries has had a 
major impact on rates of employment in the city and Leicester now has an employment rate for women that is lower than the national average (Beatty et al., 2010). Most opportunities for women in the local labour market are focused on the public sector rather than the service sector, which is the more traditional female employer. However, large factories have been established on the outskirts of the city primarily focused on the production of food and drink for the fast food and snack industries. These factories offer the opportunity to explore the experiences of women working in local industries now and will be the focus of our contemporary replication of the married women's survey.

\section{INSERT FIGURE 3 HERE}

The last of our visual approaches to these restudies was what is perhaps the most wellused visual method, photo-elicitation (Harper, 2002; Rose, 2007). As part of our interview design when revisiting the young workers we asked each participant for a photograph of themselves from around the time that the first interview took place. Although not all respondents were able to provide this, many produced photographs that were richer than we ever expected, for example, photographs of themselves on their first day at work, photographs of themselves at work or in work uniforms and often images of other significant life events. We requested photographs from the time of the interview in the hope that photo-elicitation techniques would help respondents to recall details that may otherwise have been forgotten or lain dormant in the interview. Figure 3 represents a typical photograph from this group. It shows the respondent in his leisure time enjoying the freedom that earning his own money had brought him. Without doubt, the use of the photographs such as this enriched the interview and prompted respondents to reflect back on recalled events and emotions from that period. As Harper (2002: 22-23) posits, 'photo-elicitation mines deeper shafts in to a different part of human 
consciousness than do words-alone interviews'. This, combined with the aide-memoire of the interview transcript, gave our respondents a glimpse 'back in time' and generated rich data that may otherwise have remained buried and long forgotten in the depths of individual memories.

\section{The Importance of Archival Research}

The background and contextual information relating directly to the Married Women's Project is, again, limited. For example, we are not aware of any surviving data and, as the only output from the project was a single journal article (Brown, et al. 1964), we cannot rely on published material either. However, the value of archival data in this case is immeasurable. Whilst data archives such as Qualidata do, without doubt, include valuable and rich resources which as we have already seen can encompass contextual information as well as data, other archives can also hold information relevant to past projects. In the case of the projects associated with Norbert Elias there is a clear advantage to be gained from having access to his personal archive in Germany. Much of the detailed contextual information was gleaned from visits to that archive and, within correspondence concerned with other matters, we learnt a great deal about other projects from the same time period. We also visited the National Archive at Kew where many of the records relating to DSIR are held and from here we obtained copies of letters written and received during the funding application stage including the original research proposal. In the case of the Married Women's Project the data archive at the LSE has been invaluable as Richard Titmuss's papers are held here and from this archive we located numerous sources of information on the background to the Leicester project and its links to the earlier Bermondsey study. Indeed, archive research tells us that the justification for the Leicester project was that the Bermondsey project had focused on part-time married women workers whilst the aim of the Leicester study was to provide a comparative study 
that examined the experience of women employed full-time in the textile industry. Further archival research revealed that one of the authors of the Bermondsey study (Nancy Seears) was a member of the committee that went on to approve and fund the Leicester study in recognition of the growing importance of carrying out comparative studies during that period.

We were fortunate to locate in our archival research a copy of the original research instrument used in both the Bermondsey and the Leicester studies. Access to the original instrument will enable us to replicate the original studies using the same questions. In addition, the published volume about the Bermondsey study (Jephcott et al., 1962) includes a very detailed account of the methodological approach employed and, in the appendices, much of the data is reproduced in a series of tables from which the questions used can also be derived. Again, this is an important lesson to be learnt from revisiting studies. Where archival data do not exist and where original data are no longer available, publications from past studies often include very detailed accounts of the methodology which can be used as a basis for the design of a restudy.

\section{Conclusion}

We have learnt a great deal about the value of revisiting and making use of existing datasets and have aimed to share some of these lessons here. In the current climate, where ESRC funded research teams are required not only to deposit their own data in the ESRC data archive but also to ensure that data addressing new research questions do not already exist (Moore, 2007), data reuse and restudies are likely to increase in importance and therefore these methodological debates will continue to evolve. An example of this is the use of visual methods in data reuse projects. We have made use of 
visual approaches in all three of the restudies outlined here and would argue that such an approach adds a great deal to our understanding of the history of the individuals, the workplaces and the communities we are studying. Revisiting the past through techniques such as photo-elicitation and photo-documentation alongside the act of walking the field and viewing these communities through the lens of the present has enriched our understanding of the past.

However, the value of community studies offers something more than simple data reuse. First, they return us to the analytical promise highlighted in Elias's own writings on community. The Young Worker Project and the Married Women Project in particular in our work, although they contained clear elements of this process and a desire to examine the diachronic change, they could simply have been viewed as one off cross sectional studies of youth, gender and work within an east midlands city. Yet by returning to them, years later, and re-examining the data, the ideas and debates emerging from those projects and re-interviewing respondents some forty to fifty years on, we are actually setting these studies within a process/developmental analytical framework that Elias argued for all along. If we are to full understand the continuities and changes within these localities and changes in experiences of these groups of workers, we can do this only by considering what the figurations were like in the 1950s and 1960s, what they are like now and how and what changes have taken place in the intervening years. These community groups have inevitably changed given the economic turmoil of the last fifty years and, as we have shown elsewhere, the impacts that such changes have had on these communities have been dramatic (see Author B and Author A). However, we have also found evidence that aspects of experience and community membership have persisted over that time and that the 'then' and 'now' groupings are not as different as one might expect (see Author B and Author A) - findings possible only by adopting the stance 
advocated by Elias and incorporating his broader conceptualisation of community. Second, community restudies have a clear place in addressing what Elias (1987) described as the 'retreat of the sociologists into the present'. Elias strongly critiqued the 'narrowing' of the sociologist's attention on immediate problems with a view to solving short-term issues at the expense of understanding their genesis over time. A useful recent example of this has been the rush of sociologists to comment upon and quickly explain the UK riots and public disorder that occurred in the summer of 2011. Yet, as Elias suggests 'the immediate present into which sociologists are retreating....constitutes just one momentary phase within the vast stream of humanity's development, which, coming from the past, debouches into the present and thrusts ahead possible futures (Elias, 1987: 223-4). If we are to truly understand such behaviours, be it rioters in London, the changing experiences of women and work, how the transition to adulthood has been transformed over the last forty, or the long term deindustrialization of the UK then, we would argue, community restudies may hold the key. By examining and re-examining communities over time we can explore both the continuities and changes in social relations as dynamic processes rather than as static events. Community restudies allow us to watch the 'film' of social change frame by frame rather than as one off 'polaroid' snapshot. 


\section{Acknowledgements}

We would like to thank the various individuals and institutions that have supported our research. This research received funding from the Economic and Social Research Council (grant R000223653), the University of Leicester Research Committee (grant FS14002) and the University of Leicester College of Social Science Research Development Fund (2010 and 2011). We are grateful to the staff at the Deutsches Literaturarchiv, Marbach, and to the Norbert Elias foundation for allowing us to quote Elias's archived papers. We would also like to thank colleagues at the UK National Archives, the Archives of the London School of Economics, and Moira Rankin at the University of Glasgow Archives for support in accessing papers on Norbert Elias, Ilya Neustadt and Pearl Jephcott. We are grateful to Cas Wouters, Utrecht University, and to respondent C470 for permissions to use their images in our research. Finally, we would like to thank the journal editors and the referees for their valuable comments, and thank all the participants who attended the Community re-studies conference, 12 April 2011, Nottingham, sponsored by the National Centre for Research Methods. Any final errors or omissions remain our own. 


\section{Bibliography}

Ashton, D. N. (1973) 'The transition from school to work: notes on the development of different frames of reference among young male workers', The Sociological Review, vol. 21, pp. 101-125.

Ashton, D. N. (1974) 'Careers and commitment: the movement from school to work', in Field, D. (ed) Social Psychology for Sociologists. Nelson: London.

Ashton, D. N. \& Field, D. (1976) Young Workers: From School to Work, Hutchinson, London.

Beatty, C., Gore, T. and Powell, R. (2010) Participation of Women in the Labour Market in Leicester Centre for Regional Economic and Social Research Sheffield Hallam University. http://www.shu.ac.uk/_assets/pdf/women-in-the-labour-market.pdf

Bell, C. and Newby, C. (1974) The Sociology of Community. London: Frank Cass, pp.ix-xli.

Bell, C. and Newby, C. (eds) (1971) Community Studies. An Introduction to the Sociology of the Local Community, London: Allen and Unwin.

Brown, R.K., Kirkby. J.M., and Taylor, K.F. (1964) The Employment of Married Women and the Supervisory Role, British Journal of Industrial Relations, Volume 2, pp. 23-41.

Carter, M. (1962) Home, School and Work: A Study of the Education and Employment of Young People in Britain. Pergamon Press: London.

Crow, G. (2002) 'Community Studies: Fifty Years of Theorization' Sociological Research Online, Vol. 7, No. 3, http://www.socresonline.org.uk/7/3/crow.html

Davies, C.A. and Charles, N. (2002) 'The Piano in the Parlour: Methodological Issues in the Conduct of a Restudy' Sociological Research Online, vol. 7, no. 2, http://www.socresonline.org.uk/7/2/davies.html

Department for Scientific and Industrial Research (1958) Human Sciences Committee, Minutes of the Third Meeting on Wednesday $7^{\text {th }}$ May 1958. The National Archives, REF: DSIR/17/684.

De Swann, A. (2003) Civilizing, Decivilising and Dyscivilising Processes, in Dunning, E. and Mennell, S. (eds) (2003) Norbert Elias, Volume II. Sage: London.

Elias, N. (1962) Second Memorandum, Unpublished manuscript, Deutsches Literaturarchiv, Marbach.

Elias, N. and Scotson, J. (1965) The Established and the Outsiders. London: Frank Cass.

Elias, N. (1974) 'Foreword: Towards a Theory of Communities' in C. Bell and H. Newby (editors) The Sociology of Community. London: Frank Cass, pp.ix-xli.

Elias, N. (1980) 'The civilising of parents', in The Norbert Elias Reader, eds J. Goudsblom \& S.Mennell (1998), Blackwell, London. 
Elias, N. (1987) The Retreat of Sociologists into the Present, Theory, Culture and Society, Vol. 4, pp 223-247.

Elias, N. (2000) The Civilising Process. London: Blackwell.

Elias, N. (2001) The Society of Individuals. New York: Continuum Publishing.

Frankenberg, R. (1966) Communities in Britain: Social Life in Town and Country. London: Pelican

Frankenberg, R. (1957) Village on the Border: A Social Study of Religion, Politics and Football in a North Wales Community. London: Cohen and West.

Gillies, V. and Edwards, R. (2005) Secondary Analysis in Exploring Family and Social Change: Addressing the Issue of Context. Forum Qualitative Sozialforschung / Forun: Qualitative Social Research [Online Journal], 6 (1) http://qualitative-research.net/fqs/fqseng.htm

Harper, D. (2002) Talking about pictures: A case for photo elicitation. Visual Studies, 17:

1 pp. 13-26.

Heaton, J. (2004) Reworking Qualitative Data, London: Sage.

Jephcott, P. with Sear, N and Smith, J.H. (1962) Married Women Working. London: George Allen and Unwin.

Keil, E. T., Riddell, D. S. \& Tipton, C. B. (1963b) 'A research note: the entry of school leavers into employment', British Journal of Industrial Relations, vol. 1, no. 3, pp. 408411.

Laub, J. H. and Sampson, R.J. (2003) Shared Beginnings, Divergent Lives: Delinquent Boys to Age 70. Harvard: Harvard University Press.

Mennell, S. (1992) Norbert Elias: An Introduction. Oxford: Blackwell.

Mennell, S. (1990) Decivilising Processes: Theoretical Significance and Some Lines of Research, International Sociology, 5(2), pp 205-223.

Moore, N. (2007), '(Re)using Qualitative Data', Sociological Research Online, 12 (3) http://www.socresonline.org.uk/12/3/1.html.

Neustadt, I. (1959) Application for an Extension of Special Research Grant: The Employment of Married Women in a Leicester Hosiery Factory, 24 ${ }^{\text {th }}$ November 1959. The National Archives, REF: DSIR/17/683.

Neustadt, I. and Brown, R. (1959) Unpublished Memorandum: Research into the Employment of Married Women in a Leicester Hosiery Factory, 30 $0^{\text {th }}$ October 1959. Marbach: Deutsches Literaturarchiv.

Pahl, R.E. (1984) Divisions of Labour. London: Basil Blackwell.

Pink, S. (2006) Doing Visual Ethnography: Images, Media and Representation in Research, $2^{\text {nd }}$ edition, London: Sage. 
Pink, S., Hubbard, P., O’Neill, M. and Radley, A. (2010) Walking across disciplines: from ethnography to arts practice. Visual Studies, 25: 1 pp. 1-7.

Rose, G. (2007) Visual Methodologies: An introduction to the interpretation of visual materials. $2^{\text {nd }}$ edition, London: Sage.

Rosser, C. and Harris, C. (1965) The Family and Social Change: A Study of Family and Kinship in A South Wales Town. London: Routledge and Kegan Paul.

Savage, M. (2007) Changing Social Class Identities in Post-War Britain: Perspectives from Mass-Observation, Sociological Research Online, 12(3)6 http://www.socresonline.org.uk/12/3/6.html

Savage, M. (2005) Revisiting Classic Qualitative Studies. Forum Qualitative Sozialforschung / Forum: Qualitative Social Research, [Online Journal] 6 (3) (Art. 31). Available at: http://qualitative-research.net/fqs/fqs-eng.htm

Smart, C. (2007) Personal Life: New Directions in Sociological Thinking. Cambridge: Polity.

Stacey, M. (1960) Tradition and Change: A Study of Banbury. Oxford: Oxford University Press.

Stacey, M., Bell, C., Batstone, E. and Murcott, A. (1975) Power, Persistence and Change: A second study of Banbury. London: Routledge and Kegan Paul.

Strangleman, T. (2008) Representations of Labour: Visual Sociology and Work. Sociology Compass, 2/5 pp. 1491-1505.

Suchar, C. (2004) Amsterdam and Chicago: seeing the macro-characteristics of gentrification in Knowles, C. and Sweetman, J. (eds) Picturing the Social Landscape: Visual Methods and the Sociological Imagination'. London: Routledge, pp. 147-65.

Titmuss, R.M. (1958) Application for Special Research Grant: A Study of the Employment of Married Women in a Leicester Hosiery Factory, $17^{\text {th }}$ April 1958. The National Archives, REF: DSIR/17/683.

Townsend, P. (1957) The Family Life of Old People: An Inquiry in East London. London: Routledge and Kegan Paul.

Van Krieken, R. (2011) Three faces of Civilization: 'In the Beginning All The World Was Ireland', in Gabriel, N. and Mennell, S. (eds) (2011) Norbert Elias and Figurational Research: Processual Thinking in Sociology. Blackwell: London.

Van Krieken, R. (1999) The Barbarism of Civilization: Cultural Genocide and the "Stolen Generations”, British Journal of Sociology, 50 (2), pp. 297-315.

Van Krieken, R. (1998) Norbert Elias. Routledge, London.

Willmott, P. and Young, M. (1960) Family and Class in a London Suburb. London: 
Routledge and Kegan Paul. 
Figure 1: Zone 1 Winston Parva - 1975 and 2010

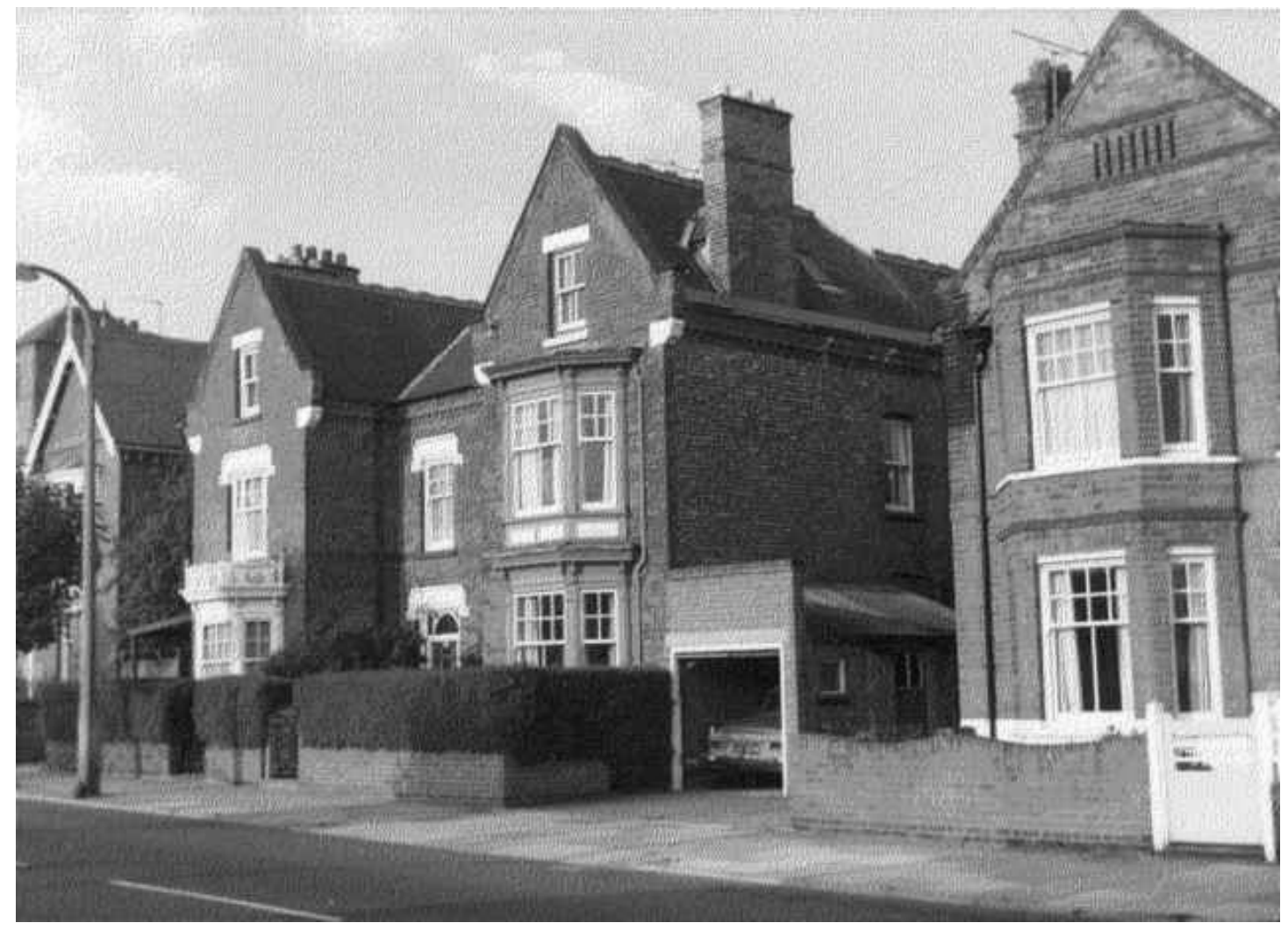

Photograph taken by Cas Wouters on a walking tour of Winston Parva with Norbert Elias, 1975.

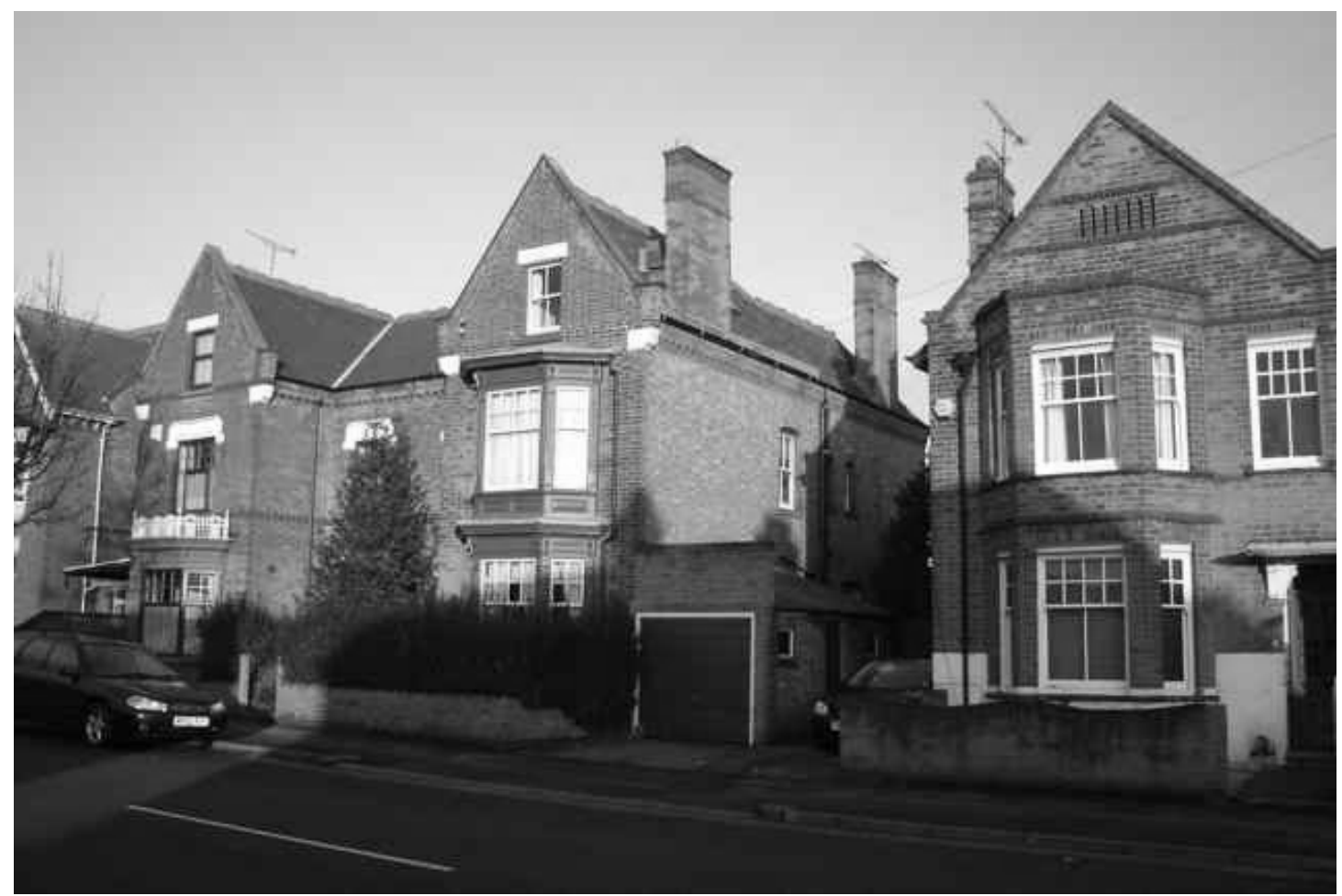

Photograph taken by authors on a walking tour of Winston Parva in 2010. 
Figure 2: N. Corah Hosiery Factory 2011

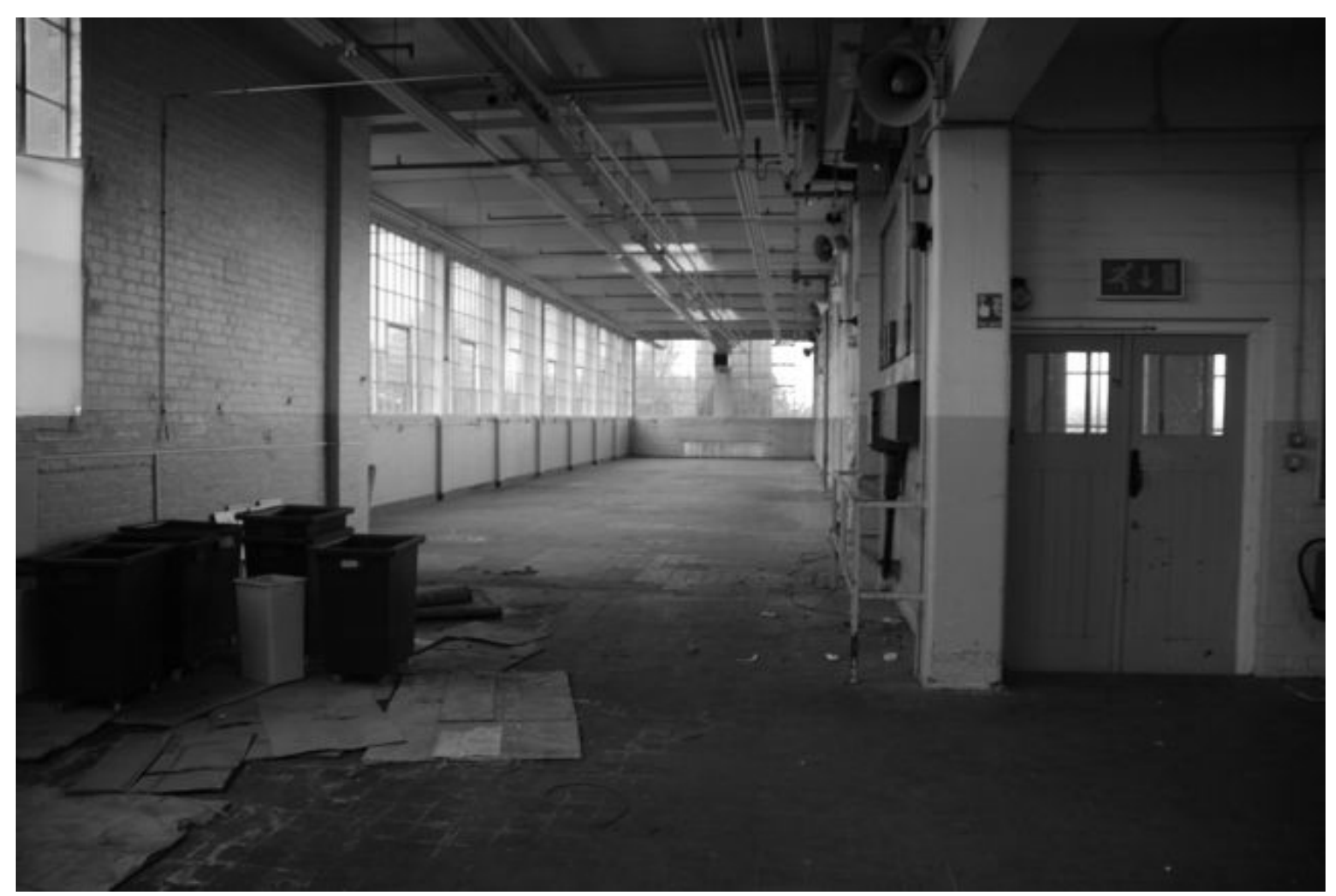

Photograph taken by authors on a walking tour of Corah in 2011. 
Figure 3: Respondent C470 'On My Motorbike’

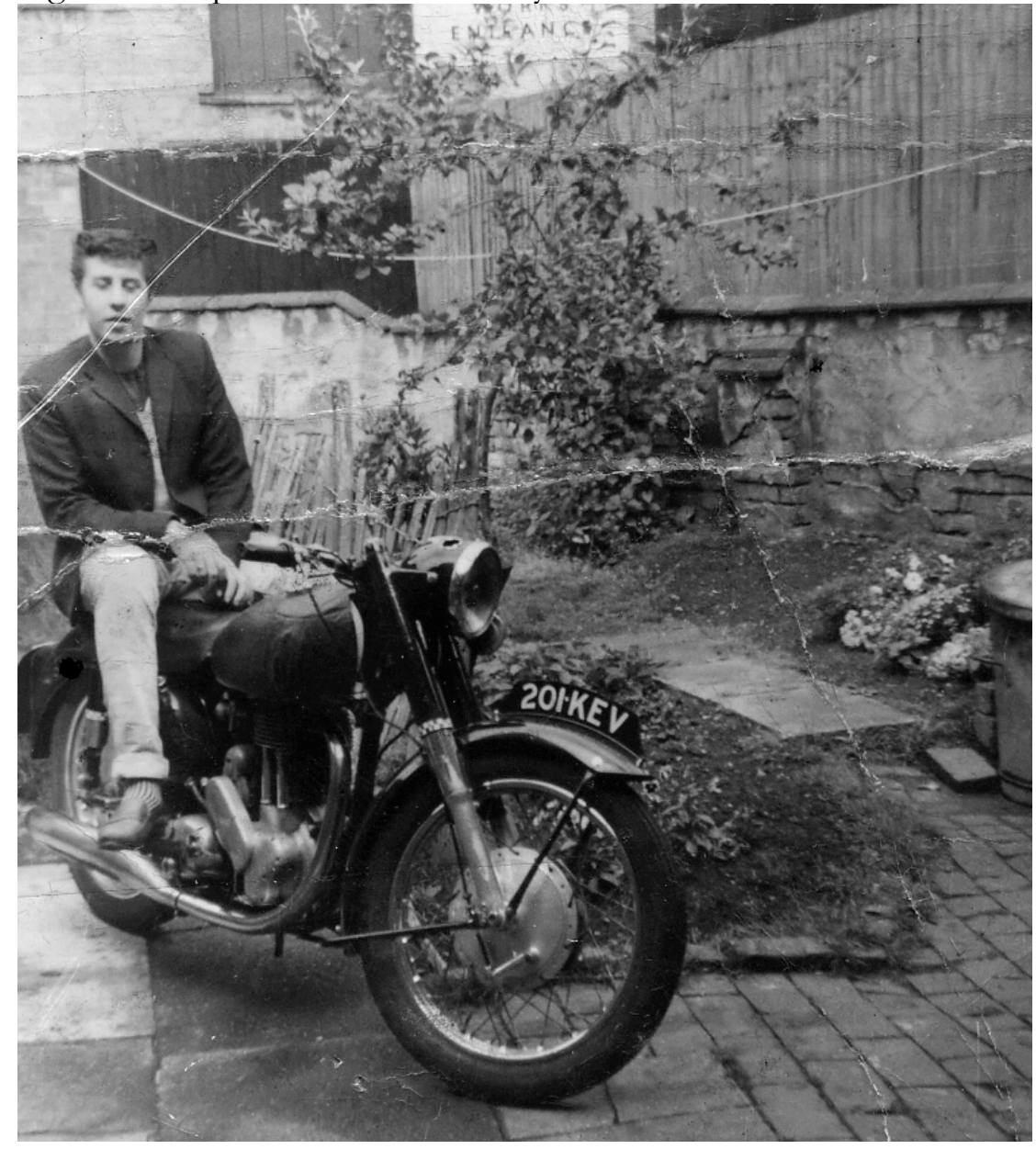

